\title{
Research and Exploration on Network Politics of College Students Education
}

\author{
Peng Liu ${ }^{1, a}$, Jingchao $\mathrm{Liu}^{2, \mathrm{~b} *}$ \\ (Xijing University) \\ ${ }^{1}$ Xijing University, No.1 Xijing Road, Chang'an District, Xi'an City, Shaanxi Province ,China \\ ${ }^{2}$ Xijing University, No.1 Xijing Road, Chang'an District, Xi'an City, Shaanxi Province ,China \\ aLiupeng1@xijing.edu.cn, bliujingchao@xijing.edu.cn
}

Keywords: College students; Network; Politics; New ideas

\begin{abstract}
As the increasing development of the network, network has infiltrated into all age groups and industries, especially the college students. Today's college students are all born in the information era, and they have adapted to the convenience brought to them by the Internet. At present how to carry out ideological and political thinking education in the internet era and how to establish a new idea of education online for college students that meeting the contemporary needs are the problems that need to be discussed and solved.
\end{abstract}

\section{Introduction}

Internet media is an important tool of public opinion. With the development of Internet information technology and mobile communication technology, it has profoundly influenced the formation and communication of public opinion, and it has increasingly influenced people, especially college students. The new campus internet media, which is mainly based on computer and mobile phone network platforms such as "two micro-ends", is highly interactive, quick to acquire information and fast to spread, providing a new carrier for the ideological and political work of university students. Taking WeChat as an example, WeChat, an instant messaging tool, has been deeply integrated into the life style of young college students and has influenced their social style. It has exerted a subtle influence on the handling of interpersonal relationship and the change of thinking habit of college students.

By exploring and enriching new methods and ways of new internet media ideological and political education, we can give full play to the role of new internet media in the era of college students' ideological and political education, and enhance the attraction and influence of new internet media education. According to the characteristics of new internet media, we pay attention to the innovation of education method form and content, and use the all-media platform to visualize, materialize and digitize the contents of ideological and political education, in order to make it enter the students' vision and brain in a silent way, and practically improve the pertinence and effectiveness of ideological and political education.

\section{Under the Guidance of the Scientific Development Concept, Construct a New Way of Thinking on Political Thinking Education}

General secretary Xi Jinping's cyber view points out that " Without cyber security, there will be no national security, and without informatization, there will be no modernization". At present, the ideological and political education in colleges and universities is also faced with the embarrassment in combining with the Internet. How to combine the traditional ideological and political education with the Internet and explore a new way of Internet political education that suitable for contemporary college students is extremely important.

Keep Pace with the Times and Update Your Ideas. Under the guidance of the scientific development concept, relying on the government's leading, we can use the marxist methodology to deal with disadvantage of digital carrier, and use the law of development in the network ideological 
education. The Internet has many basic characteristics, such as timeliness, validity, correlation and virtual sex. Based on the harmonious campus, we should follow the party's line, and grasp the network ideological education's aim. We need to focus on the students' belief education, and make sure the timeliness in the ideological education. In this way, we can keep pace with the times and update our ideas.

Create an Online Platform for Online Interaction. Based on the actual situation of students, a platform is established through the network to effectively interact between students, such as tencent QQ, WeChat, weibo and other new education model for thinking and politics. So it create a multi-angle and all-round education platform. It uses the network's multimedia technology function to carry out theme sites, such as "online party classes", "online BBS", "online psychological inquiry" etc, and publishes the psychological teachers' emails, in this way students can connect with teachers unimpeded. In the education platform, students can grasp the information brought by new media and obtain a silent education effect.

Establish Safety System and Guard Against Network Behavior.In recent years, Internet fraud happens frequently. How to teach young students to judge the authenticity of the information has become a new subject in education. To perfect the management system of network politics education, we must guide students to thought and regulate the network in system. We need to admonish the behaviors beyond the sphere of reason, give prompt notice or arrangement for students' certain legitimate claims. When the topic for disscusion is more controversial, we reserve our opinion, and make students be persuaded by authority figures and proper speech. We should actively communicate with students to discuss topics for the temporary urgent situation and focus. Only in this way can we ensure the positive development of campus speech environment and present a network with clean environment and smooth information.In addition, it is also necessary to strengthen the monitoring and management of new carriers on the network, and distribute special staff to supervise related situations, so that unhealthy information on the network is hidden and harmful information is minimized.

\section{On the Basis of the New Network Situation, We Should Take the Initiative to Give Play to the Immediacy of Thinking and Politics Education}

Create a Main Position Site. Colleges and universities should make full use of the network to establish the main position, and combine the ideological and political education with the new network effectively. Because contemporary college students are born in the network age, they are learning knowledge that they needs through the network every day, and have already adapted to the reality of contemporary social development. Nowadays, the Internet has gradually become a necessity for them to live and study. Therefore, colleges and universities can effectively use the main position of the Internet to establish a satisfactory website that is easy to accept for college students. At the same time, students can also use the Internet to live in a positive and real network. It can make students to minimize the impact of adverse web sites on them, and to really graft ideological politics into the web.

Update Your Website Daily. The key to keep the vitality of the new network carrier lies is the content. Only creative, innovative and colorful content can be accepted by the students. The way of this work should be improved on the basis of previous thinking and politics. At the same time, you can also set up a scientific and reasonable, a more attractive ideological education theme site. For example, we can use the professional course web site or the information from the web to spread the correct world outlook, the outlook on life and values. They can often infiltration in political science, economics, culture, ethics, aesthetics, sociology and other disciplines. In this way, not only the can the initiative to meet the needs of students, make students from the Internet to gain knowledge about humanities and social science, but also it can indirectly enhance the influence of network ideology and politics education, so as to achieve the ideal effect of win-win. 


\section{In the Two-way Interactive Network Model, Actively Carry Out Ideological and Political Education}

Use QQ, WeChat and Other Chat Tools. Face to face communication, a lot of time is scary, it cannot express oneself want to say directly. On the Internet, many people wrap themselves in fake names and messages. As college student managers, they will also encounter such problems. Many students have many ideas and dissatisfaction in their hearts, but they take many objective factors into consideration and will not express them to others. But they often can use the software such as post bar, BBS to tell their inner world. Therefore, QQ, WeChat and other software can make the users have affective communication by virtual environment, so that students will not obscure their own words. However, as a college administrator, we should also pay attention to the art and methods of language and avoid self-defeating.

Establish QQ Groups, WeChat Common Platform. A good network platform will make students want to browse from time to time, so using blogs, MSN, QQ groups and WeChat platform, students' needs in life or learning can be timely published. Students also come here frequently to see if there is information suitable for them. it can form a great demand force. In such a situation, some patriotic and positive things can be released among students, such as correct guidance and admonition. Only in this way can we guide the college students correctly to realize the network, information and scientific thinking mode.

\section{Summary}

Network is an important part of college students' life and study. The Internet has brought a new and convenient way of cognition to college students, which to some extent has also brought a variety of shocks to college students, whose ideological and moral values have slightly deviated. Therefore, only we can actively change the single way of thinking and morality education, and exert some influence on college students in terms of ethics and other aspects in view of the openness of the network. So, in this process, the choice of new path of network ideology and morality education becomes particularly important, making college students gradually complete the spiritual baptism in the process of network activities.

Campus network is the public opinion propaganda front of the emerging ideology and politics education that receives the most attention from colleges and universities. Colleges and universities should increase the allocation of campus network funds, technologies, talents and hardware facilities, and actively build education platform for spreading advanced culture, promoting scientific theory and promoting campus integrity. And We should closely combine the CPC central committee propaganda education, find the ideological and political education combining site, pass new rich content through the way that the students interested in to make them think the enlightenment and inspiration on the information. In this way, we can attract students consciously pay the initiative to participate, and let the students accept the ideological and political education in quiet way.

With the victory at the 19th congress, our country has entered a new era, the ideological and political education workers, should not forget the beginner's mind. And we should keep in mind that the mission, closely around the new features of new era, make full use of new internet media advantage, fusion new era characteristics, holding the great banner of socialism with Chinese characteristics, rally forces powerful ideological and political education, to achieve ideological education work to strive for a comprehensive victory.

\section{References}

[1] $\mathrm{Xi}$ He. Opening up a new position of network ideology and politics [J]. People BBS,2018(19):114-115. (In Chinese) 
[2] Xiangyang $\mathrm{Xu}$, Yunling Chen. Study on improving the discourse power of network ideology and politics in universities in the context of big data [J]. Journal of huaibei vocational and technical college, 2008,17(04):8-10. (In Chinese)

[3] Ying Qiu, Mingming Li. Study on ideological and political education in universities from the perspective of new media $[\mathrm{J}]$. Journal of hainan radio and television university, 2008,19(02):117-120+139. (In Chinese)

[4] Guoxin Yi. Research on the education mode of "easy class +" in university network sizheng education [J]. Journal of minxi vocational and technical college, 2008,20(02):88-91. (In Chinese)

[5] Xiangyang Xu . Reconstruction of discourse mechanism of ideological and political education in universities in the context of micro media [J]. Journal of hubei correspondence university, 2008,31(12):75-76. (In Chinese)

[6] Liang Zhao. Improvement path of ideological and political thought in universities from the perspective of Internet [J]. Journal of hebei university of engineering (social science edition), 2008,35(02):79-80. (In Chinese)

[7] Yan Ren. Path exploration to improve the educational function of high school network culture [J]. Journal of central north university (social science edition), 2008,34(03):145-148. (In Chinese)

[8] Yang Xu. Study on ideology and politics education model in universities under the background of "Internet +" [J]. Intelligence,2018(18):139. (In Chinese)

[9] Hao Xu. Exploration on the path of network ideology and politics in colleges and universities in the new media era $[\mathrm{J}]$. Teaching education (higher education BBS),2018(18):68-69. (In Chinese)

[10] Shengbin Fan. "post-90s" female college students' quality improvement strategy from the perspective of "Internet + " [J]. Journal of shengli college of China university of petroleum, 2008,32(02):63-65. (In Chinese) 